\title{
DETEKSI MOLEKULER GEN FUSION (F) DAN ANALISIS PERBANDINGAN BEBERAPA ENZIM RESTRIKSI SEBAGAI PENENTU PATOTIPE VIRUS NEWCASTLE DISEASE
}

\author{
Medania Purwaningrum $^{1}$, Verawati $^{2}$, Aris Haryanto ${ }^{1}$ \\ ${ }^{1}$ Departemen Biokimia dan Biologi Molekuler, Fakultas Kedokteran Hewan, \\ Universitas Gadjah Mada, Yogyakarta, Indonesia 55281 \\ ${ }^{2}$ Laboratorium Bioteknologi, Balai Besar Veteriner Wates, Yogyakarta, Indonesia 55602 \\ Email: ${ }^{1}$ medania@ugm.ac.id, ${ }^{2}$ verawatisutopo@gmail.com, ${ }^{1}$ arisharyanto@ugm.ac.id
}

\begin{abstract}
Newcastle disease (ND) is a contagious viral disease caused by Avian Paramyxovirus Serotype-1 (APMV-1). This viral infection is responsible for devastating outbreak by attacking nerve, respiration, and also digestive system. This disease often followed with decreasing of eggs production and also responsible for economic losses in the poultry industries around the globe. The main goal was to differentiate virulent or avirulent strain of ND virus from $F$ gene, which is the virulent marker of ND virus, by Reverse Transcription Polymerase Chain Reaction (RT-PCR) and Restrion Enzyme Analysis using BamH1, Hin 1l, and Apa 1. Ten ND virus samples came from Animal Disease Investigation Center (ADIC) Wates virus collection, collected from field case in 2012-2013. Newcastle disease virus was collected by extraction from the samples. The RNA product of extraction were used as a template for amplification in RT-PCR. The target of RT-PCR amplification was $F$ gene. The results indicated positive reaction due to existing of DNA fragment band in size of $767 \mathrm{bp}$. RT-PCR and Restrion Enzyme Analysis can be used as tool to determine the pathotype of ND virus showed different restriction visualized by gel agarose electrophoresis.
\end{abstract}

Keywords: Newcastle Disease Virus, F gene, RT-PCR, restriction enzyme, pathotype

\section{PENDAHULUAN}

Newcastle disease (ND) adalah penyakit infeksius pada unggas yang dapat menginfeksi lebih dari 200 spesies unggas sehingga menjadi perhatian utama di industri perunggasan di dunia karena menyebabkan kerugian yang besar (Kim et al., 2008). Virus ND pada unggas ini termasuk dalam daftar penyakit list A oleh Office Internationale de Epizootics (OIE) sehingga perlu langkah antisipatif kebijakan dalam hal mengontrol wabah penyakit tersebut. Newcastle disease yang disebut juga sebagai penyakit tetelo disebabkan oleh virus Newcastle disease yang diklasifikasikan masuk dalam Mononegavirales, famili Paramyxoviridae, genus Avulavirus, spesies Avian paramyxovirus serogrup Avian paramyxovirus tipe 1 (APMV-1) (Aldous et al., 2010). Virus ND mampu menginfeksi lebih dari 200 spesies unggas tetapi tingkat keparahan penyakit yang ditimbulkan oleh infeksi virus ND bervariasi, tergantung dari hospes (jenis unggas) dan strain virus ND. Strain virus ND yang kurang patogen juga dapat menyebabkan penyakit yang parah pada unggas apabila 
diikuti dengan infeksi sekunder oleh mikroorganisme lain dan kondisi lingkungan yang buruk (OIE, 2012). Virus ini bereplikasi di sitoplasma, beramplop, pleomorfik, termasuk kelompok single strand RNA, negative-sense, nonsegmented, dan mempunyai panjang genom sekitar $15,2 \mathrm{~Kb}$ yang memiliki 6 open reading frame (ORF) yang mengkode nucleoprotein (NP), phosphoprotein $(\mathrm{P})$, protein matrix $(\mathrm{M})$, protein fusion $(\mathrm{F})$, hemagglutinin-neuraminidase (HN) dan RNA polimerase (L). Dua protein non struktural V dan W (Kim et al., 2008; Murphy et al., 2008). Protein haemaglutinin-neuroamidase (HN) glikoprotein dari virion yang berikatan dengan protein asam sialat membran sel berfungsi sebagai reseptor untuk melekatkan virion ke sel hospes. Hal tersebut memicu protein Fusion (F) memulai fusi antara amplop virus dengan membran sel hospes, setelah masuk ke dalam sel hospes nukleokapsid (NP) keluar dari protein matriks (M) menuju ke sitoplasma. Enzim RNA polimerase kompleks mentranskripsi genom virus RNA menjadi mRNA untuk sintesis protein virion baru. Perlekatan polimerase kompleks pada nukleokapsid (NP) diperantarai oleh protein P, dimana aktifitas katalitiknya diperankan oleh protein L (Dortmans et al., 2011). Amplop virus ND terdiri atas dua macam glikoprotein yaitu HN dan F. Protein tersebut memiliki peranan penting dalam infeksi virus ke sel hospes. Penggabungan kedua protein tersebut sangat menentukan dalam mekanisme infeksi virus ND. Virus ND diklasifikasikan menjadi tiga patotipe utama berdasarkan tingkat keparahan tanda-tanda klinis pada ayam, yaitu velogenik (highly virulen), mesogenik (intermediate virulen) dan lentogenik (low virulen) (Tan et al., 2009; Dortmans et al., 2011; Purwaningrum et all, 2018 ).

Virus ND pertama kali ditemukan di pulau Jawa, Indonesia dan di Newcastle, Inggris pada tahun 1926. Newcastle disease masih menjadi permasalahan penting karena merupakan salah satu penyakit yang menimbulkan kerugian ekonomi pada industri peternakan unggas baik di Indonesia maupun di dunia (Murphy et al., 2008). Walaupun hanya satu serotipe virus ND yang ada, namun ada dua subdivisi yaitu kelas I dan kelas II. Virus kelas I memiliki 9 genotipe (1-9) (Mase dan Kanehira, 2012) menyerang unggas air dan kebanyakan tidak virulen untuk ayam. Virus kelas II telah diisolasi dari unggas dan hewan peliharaan yang dibagi menjadi 10 genotipe (I - X). Genotipe I terdiri dari virus ND avirulen, genotipe II, III, IV panzootik pertama, genotipe V panzootik kedua, genotipe VI panzootik ketiga, genotipe VII panzootik keempat ND yang masih berlangsung hingga kini, genotipe IX dilaporkan di China, dan genotipe $\mathrm{X}$ dilaporkan di Taiwan. Penyebaran penyakit ini hampir di seluruh dunia dan menyebabkan kerugian ekonomi yang besar di industri perunggasan (Dortmans et al., 2011). 
Patotipe virus ND penting untuk diketahui karena berdampak pada mortalitas dan morbiditas berdasarkan gejala klinis pada ayam. Ayam yang terinfeksi virus ND tipe velogenic viscerotropic (VVND) atau ND bentuk pencernaan mortalitasnya dapat mencapai 100\% (Murphy et al., 2008). Ayam yang terinfeksi virus ND tipe velogenic neurotropic (VNND) atau ND bentuk saraf morbiditasnya dapat mencapai 100\%, mortalitasnya mencapai $50 \%$ pada ayam dewasa dan $90 \%$ pada ayam muda. Ayam yang terinfeksi oleh virus ND tipe mesogenik menyebabkan gangguan pernapasan dan penurunan produksi telur. Mortalitas biasanya rendah, kecuali pada ayam muda. Ayam yang terinfeksi oleh virus ND tipe lentogenik tidak menyebabkan penyakit pada ayam dewasa. Pada ayam muda mungkin akan terlihat gangguan pernapasan (Adi et all., 2008; Murphy et al., 2008; Sianita et all., 2011).

Strain virus ND dapat dibedakan virulensinya berdasarkan cleavage site, aktivitas hemaglutinin-neuraminidase, dan fusion glikoprotein. Pada strain virulen prekursor clevage site aktif, sedangkan pada strain avirulen prekursor protein tidak aktif. Fusion protein menghasilkan prekursor glikoprotein, F0 akan terpotong menjadi F1 dan F2 dengan bantuan protease (Dortmans et al., 2009; Murphy et al., 2008).

Penentuan patotipe virus ND biasanya dilakukan dengan uji in vivo seperti : mean death time (MDT) pada telur ayam berembrio kurang dari 60 jam untuk tipe velogenik, 60-90 jam untuk tipe mesogenik, dan lebih dari 90 jam untuk tipe lentogenik; skoring derajat keparahan dengan metode intra cerebral pathogenicity index (ICPI) pada ayam umur sehari 0-2; intravenous pathogenecity index (IVPI) pada ayam umur 6 minggu dengan skor 02,8 (Alexander, 1991; Alexander, 2003). Laporan terkini menyebutkan sekuensing asam amino dari reverse transcription polimeration chain reaction (RT-PCR) gen F virus ND dapat membedakan patotipe virus ND dengan phenylalanin pada urutan asam amino ke 117 untuk velogenik dan mesogenik, dengan leusin untuk tipe low virulen. Tipe velogenik, mesogenik merupakan strain virus ND yang virulen, sedangkan tipe lentogenik merupakan strain low virulen. Strain virus ND virulen dan avirulen dapat dibedakan dengan melakukan RT-PCR dan restriction endonuclease analysis (Lee et al., 2008; Miller et all., 2010; OIE, 2012; Purwaningrum, 2014).

Restriction enzyme analysis disebut juga restriction endonuclease analysis (adalah cara untuk memotong dan memanipulasi segmen DNA pada daerah spesifik dengan berbagai enzim restriksi. Metode PCR-REA merupakan metode pemotongan DNA dari produk PCR dengan enzim restriksi untuk membedakan strain APMV-1 virulen dan avirulen dengan REA 
menjadi beberapa fragmen DNA yang terpotong atau DNA yang tetap utuh karena tidak terpotong (Mase dan Kanehira, 2012).

Penentuan patotipe virus ND dari gejala klinis sulit dibedakan di lapangan. Penentuan patotipe virus ND dengan MDT TAB, ICPI, IVPI membutuhkan waktu yang lama dan sulit dilakukan, sehingga perlu dilakukan penentuan patotipe virus ND secara sederhana, cepat, dan tepat secara molekuler dengan RT-PCR dan analisis menggunakan enzim restriksi pada target gen F. Sehubungan dengan kondisi tersebut metode RT-PCR dan analisis menggunakan beberapa enzim restriksi yang dikembangkan oleh Mase dan Kanehira (2012) dapat diaplikasikan untuk menentukan patotipe virus ND pada ayam.

\section{BAHAN DAN METODE}

Penelitian ini menggunakan 10 sampel kasus ND pada ayam berupa suspensi virus dari cairan alantois telur ayam berembrio (TAB) koleksi BBVet Wates D. I. Yogyakarta. Materi yang diperlukan dalam penelitian ini adalah kit isolasi RNA virus High Pure Viral Nucleic Acid Kit (nomor katalog: 11-858-874-001) dari Roche dan kit RT-PCR SuperScript $^{T M}$ III One-Step RT-PCR with Platinum Taq (nomor katalog: 12574-026) dari Invitrogen. Gel agarose UltraPure ${ }^{\mathrm{TM}}$ Agarose Invitrogen (nomor katalog: 16500-100), Buffer 1x Trizma base-Boric acid-EDTA (TBE), Phosphat Buffer Saline (PBS), Florosafe DNA Stain dari 1st BASE (larutan pewarna asam nukleat), aquabidest, aquadest, Blue Loading Dye (nomor katalog: 10816-015), 1 kb DNA Ladder dari Promega (nomor katalog: 29278801), 1 kb DNA Ladder Bioron (nomor katalog: 306009), 100 bp DNA Ladder (nomor katalog: 15628-019), sepasang primer (disajikan pada Tabel 1), enzim restriksi juga diperlukan dalam penelitian ini (disajikan pada Tabel 2) BamH1 (lot : 00117154).

Tabel 1. Primer Gen Penyandi Protein F Virus ND (Mase dan Kanehira, 2012)

\begin{tabular}{llc}
\hline Target Gen & Sekuen Primer & Produk PCR \\
\hline gen F & F: 5'-TGGAGCCAAACCGCGCACCTGCGG-3' & 767 bp \\
& R: 5'-GGAGGATGTTGGCAGCAT-3' & \\
\hline
\end{tabular}

Tabel 2. Pola Pemotongan Produk RT-PCR Gen F NDV dengan Enzim Restriksi

\begin{tabular}{|c|c|c|}
\hline \multirow{3}{*}{$\begin{array}{l}\text { Enzim Restriksi } \\
\text { BamHI }\end{array}$} & Restriction Site & Perkiraan Besar Produk (bp) \\
\hline & $5^{\prime} \ldots \mathrm{G}^{\downarrow} \mathrm{G}$ A T C C... $3^{\prime}$ & Virulen $: 281,486$ \\
\hline & $3^{\prime} \ldots \mathrm{C} \mathrm{C} \mathrm{T} \mathrm{A} \mathrm{G}_{\uparrow} \mathrm{G} \ldots 5^{\prime}$ & Avirulen : 52, 281, 434 \\
\hline \multirow[t]{2}{*}{ Hinll } & $5^{\prime}, \ldots \mathrm{G} \mathrm{R}^{\downarrow} \mathrm{C}$ G Y C... $3^{\prime}$ & Virulen : tidak terpotong (767) \\
\hline & $3^{\prime} \ldots \mathrm{C} \quad \mathrm{Y} \mathrm{G} \mathrm{C} \mathrm{C}_{\uparrow} \mathrm{R}$ G... $5^{\prime}$ & Avirulen : 11, 101, 293, 362 \\
\hline ApaI & $\begin{array}{l}5^{\prime}, \ldots \text { G G G C C C } \ldots 3^{\downarrow}, \\
3^{\prime} \ldots \mathrm{C}_{\uparrow} \mathrm{C} \text { C G G G.. }{ }^{\prime}\end{array}$ & Tidak terpotong \\
\hline
\end{tabular}


Ekstraksi RNA virus ND menggunakan High Pure Viral Nucleic Acid Kit (nomor katalog: 11-858-874-001) dari Roche. Prosedur ekstraksi sesuai petunjuk dari kit dan selanjutnya diperoleh RNA virus ND.

Proses RT-PCR gen penyandi protein F dilakukan dalam beberapa tahapan reaksi, yaitu diawali dengan satu siklus reverse transcription (RT) pada suhu $50^{\circ} \mathrm{C}$ selama 30 menit. Tahapan amplifikasi PCR terdiri dari 3 tahap yaitu denaturasi pada suhu $94^{\circ} \mathrm{C}$ selama 30 detik, annealing pada suhu $50^{\circ} \mathrm{C}$ selama 30 detik, dan ekstensi pada suhu $68^{\circ} \mathrm{C}$ selama 1 menit. Tahapan amplifikasi PCR dilakukan secara berulang sebanyak 40 siklus. Proses PCR ini diawali dengan tahap pre-denaturasi pada suhu $94^{\circ} \mathrm{C}$ selama 2 menit dan diakhiri dengan final ekstensi pada suhu $68^{\circ} \mathrm{C}$ selama 5 menit. Kontrol positif virus ND yang sudah divalidasi oleh BBVet Wates D. I. Yogyakarta digunakan sebagai kontrol positif dalam amplifikasi ini, sedangkan kontrol negatif berasal dari aquabidest $\left(\mathrm{dH}_{2} \mathrm{O}\right)$ steril yang tidak mengandung virus.

Elektroforesis DNA dilakukan pada gel agarose 1,5\% dengan pewarnaan florosafe dalam $100 \mathrm{ml}$ larutan TBE buffer $1 \mathrm{x}$. Proses elektroforesis berjalan selama \pm 60 menit pada tegangan 100 Volt. Produk RT-PCR hasil elektroforesis dapat divisualisasikan melalui UV Transilluminator. Salah satu sumurannya dengan $5 \mu 1$ penanda molekuler (DNA ladder 100 $b p)$.

Komponen yang dibutuhkan untuk analisis menggunakan beberapa enzim restriksi seperti Bam H1, Hinll, dan Apal sebanyak $1 \mu \mathrm{l}$ dimasukkan dalam tube 0,2 $\mathrm{ml}$. Proses analisis menggunakan beberapa enzim restriksi ini membutuhkan waktu 1-16 jam pada suhu $37^{\circ} \mathrm{C}$. Pola pemotongan produk RT-PCR virus ND dengan enzim tersebut dapat membedakan virus ND yang virulen dan avirulen setelah produk REA dielektroforesis. Pola pemotongan DNA nya di analisis dengan CLC sequence viewer 6.8.1 dan lebih diteguhkan dengan hasil sekuensing beberapa sampel yang dikirimkan ke PT. Genetika Science. Produk pemotongan DNA dengan REA hasil elektroforesis pada gel agarose $2 \%$ dapat divisualisasikan melalui UV Transilluminator.

\section{HASIL DAN PEMBAHASAN}

Sampel yang digunakan dalam penelitian ini merupakan sampel kasus ND pada ayam koleksi Balai Besar Veteriner (BBVet) Wates selama periode 2012-2013. Sebanyak 10 sampel virus ND berupa suspensi virus dari cairan alantois telur ayam berembrio specific antibody negative (TAB SAN) di uji dalam penelitian ini. Daftar sampel penelitian disajikan pada Tabel 3. 
Tabel 3. Daftar Sampel Penelitian

\begin{tabular}{clll}
\hline No Sampel & Kode Sampel & Asal Hewan & Asal Sampel \\
\hline 1 & $0081 / 01 / 2013$ & Ayam broiler & Sleman, Yogyakarta \\
2 & $0366 / 03 / 2013$ & Ayam buras & Bambanglipuro, Bantul \\
3 & $0496 / 04 / 2013$ & Ayam petelur & Ginderejo, Karanganyar \\
4 & $0627 / 04 / 2013$ & Ayam broiler & Kartasura, Karanganyar \\
5 & $0663 / 04 / 2013$ & Ayam buras & Galur, Kulon Progo \\
6 & $0815 / 05 / 2013$ & Ayam petelur & Pilangkenceng, Madiun \\
7 & $0819 / 05 / 2013$ & Ayam broiler & Sukomoro, Magetan \\
8 & $1860 / 11 / 2012$ & Ayam buras & Pengasih, Kulon Progo \\
9 & $1651 / 11 / 2012$ & Ayam broiler & Galur, Kulon Progo \\
10 & $1406 / 08 / 2013$ & Ayam buras & Trirenggo, Bantul \\
\hline
\end{tabular}

Pada penelitian ini, identifikasi virus ND dan penentuan patotipe virus dilakukan dengan metode RT-PCR dan analisis patotipe ND menggunakan beberapa enzim restriksi. Parameter yang dipakai dalam RT-PCR ini adalah adanya amplifikasi pada gen penyandi protein F virus ND yaitu sebesar 767 bp (Purwaningrum, 2014). Tahapan ekstraksi virus ND dari cairan alantois TAB SAN dan RT-PCR ini dilakukan di Laboratorium Biokimia Fakultas Kedokteran Hewan Universitas Gadjah Mada dan Laboratorium Bioteknologi Balai Besar Veteriner (BBVet) Wates D. I. Yogyakarta. Hasil elektroforesis dari tahap amplifikasi RTPCR ini ditunjukkan pada Gambar 1.

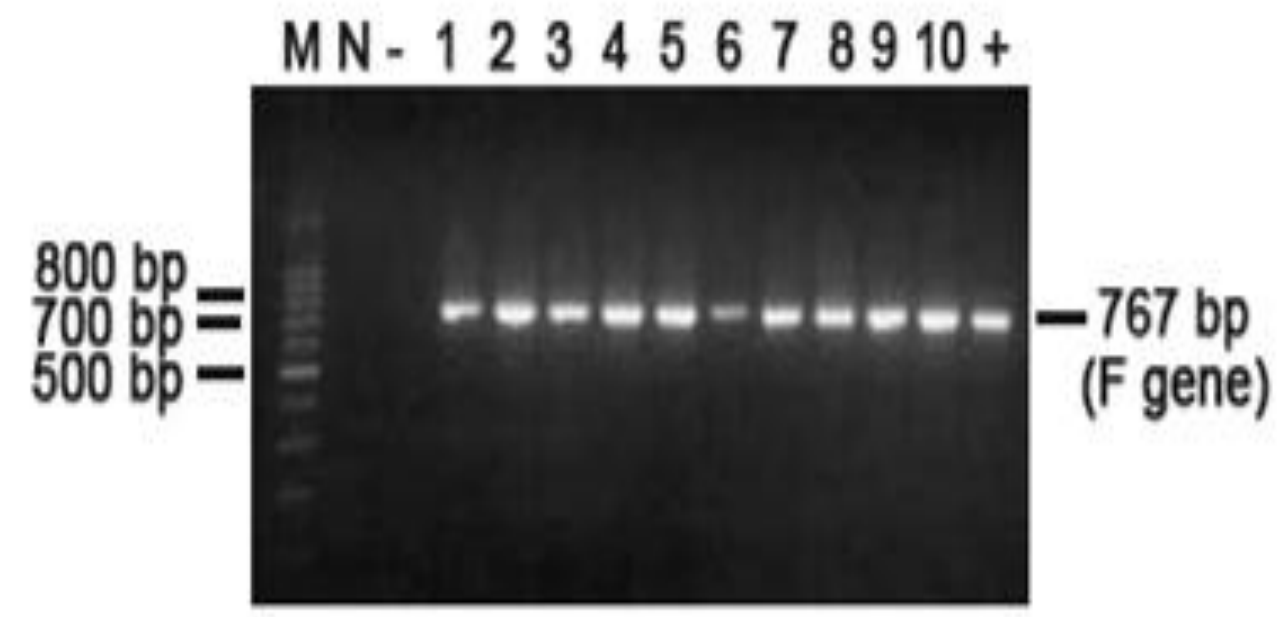

Gambar 1. Hasil Amplifikasi Gen Penyandi Protein F (767 bp) 10 Sampel Koleksi BBVet Wates dengan Metode RT-PCR

Keterangan : Lajur M adalah DNA Ladder 100 bp, lajur N adalah non template control (NTC), sedangkan lajur - adalah kontrol negatif. Lajur 1-10 menunjukkan nomor sampel yang menunjukkan hasil positif. Lajur K+ adalah kontrol positif yang telah divalidasi oleh BBVet Wates.

Lajur M adalah DNA Ladder (Marker) yang berukuran 100 bp. Analisis hasil elektroforesis 100 Volt pada gel agarose 1,5 \% dapat dilihat pada Gambar 5 mengindikasikan bahwa fragmen DNA sebesar 767 bp merupakan gen penyandi protein F (Mase dan Kanehira, 2012) teramplifikasi pada semua sampel. Kontrol positif (lajur + ) telah divalidasi oleh BBVet Wates. Kit invitrogen tanpa template dan tanpa Aquabidest $\left(\mathrm{dH}_{2} \mathrm{O}\right)$ untuk NTC. Aquabidest 
digunakan sebagai kontrol negatif pada lajur 3 yang menunjukkan tidak adanya amplifikasi pada kondisi RT-PCR yang sama.

Sepuluh sampel positif ND tersebut dibedakan patotipenya dengan metode analisis menggunakan beberapa enzim restriksi kemudian dielektroforesis DNA (Fatchiyah, et al., 2011; Ngili, 2010). Penentuan patotipe virus ND dapat dibedakan dari pola pemotongan DNA dengan metode RT-PCR dan analisis menggunakan beberapa enzim restriksi. Hasil analisis menggunakan beberapa enzim restriksi di elektroforesis untuk membedakan strain virus ND virulen dan avirulen. Metode analisis menggunakan enzim restriksi Bam H1 yang berasal dari bakteri Bacillus amyloliquefaciens $\mathrm{H}$. Enzim restriksi Bam HI akan memotong pada urutan nukleotida DNA sebagai berikut 5' ...G ${ }^{\downarrow} \mathrm{G}$ A T C C... 3' dan 3' ...C C T A G G... 5'. Hasil analisis menggunakan enzim restriksi $\mathrm{Bam} \mathrm{Hl}$ dapat membedakan strain virulen dan avirulen virus ND setelah di elektroforesa DNA 100 Volt dengan konsentrasi gel agarose 3\% yang dibuktikan dengan terlihat perbedaan pola pemotongan virus ND virulen dan avirulen dari kesepuluh sampel. Pola pemotongan Enzim restriksi Bam H1 ditunjukkan pada Gambar 2.

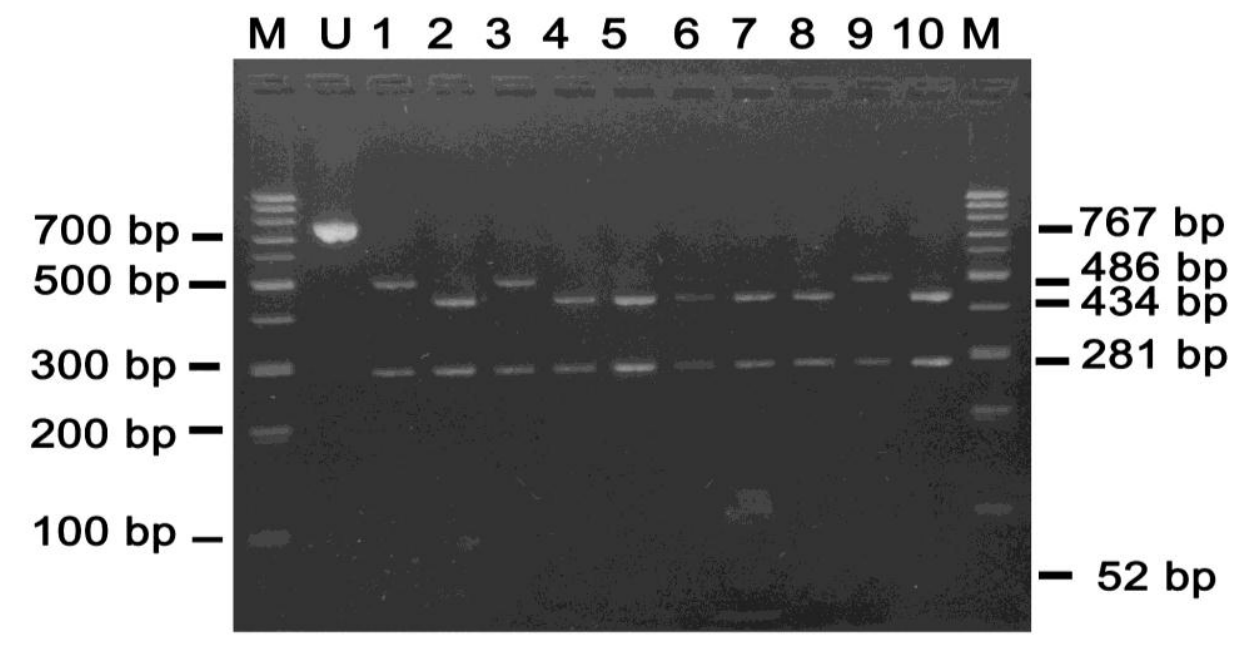

Gambar 2. Hasil Amplifikasi Penentuan Patotipe Virus ND dengan Metode RT-PCR Menggunakan Enzim Restriksi Bam H1

Keterangan : Lajur U merupakan kontrol positif ND gen F yang sudah divalidasi oleh BBVet Wates dan tidak dipotong dengan enzim restriksi. Lajur 1, 3, dan 9 terpotong menjadi 2 fragmen DNA. Lajur 2, 4, 5, 6, 7, 8, 10 terpotong menjadi 3 fragmen oleh enzim restriksi. Lajur M adalah DNA Ladder 100 bp.

Virus ND yang avirulen memiliki 1 restriction site Bam $H 1$ yaitu pada nukleotida nomor 281 sehingga menghasilkan 2 pola pemotongan DNA setelah di elektroforesa pada gel agarose yaitu 281 bp dan 486 bp. Virus ND virulen memiliki 2 restriction site Bam H1yaitu pada nukleotida nomor 281 dan 333 nsehingga menghasilkan 3 pola pemotongan DNA setelah di elektroforesa pada gel agarose yaitu 52 bp, 281 bp, dan 434 bp (Purwaningrum, 2014). 
Metode analisis menggunakan enzim restriksi yang dilakukan juga dengan enzim restriksi Hin1l dari bakteri Haemophilus influenzae RFL1. Enzim restriksi ini dapat membedakan virus ND virulen dan avirulen dengan pola pemotongannya. Enzim restriksi Hinll akan memotong pada urutan nukleotida DNA sebagai berikut 5' ...G R ${ }^{\downarrow} \mathrm{C}$ G Y C... 3' dan 3' ...C Y G C $\uparrow$ R G... 5' dimana $R$ adalah basa purin yaitu adenin atau guanin (A/G) dan $\mathrm{Y}$ adalah basa pirimidin yaitu sitosin atau timin $(\mathrm{C} / \mathrm{T})$. Hasil analisis menggunakan enzim restriksi Hinll dapat membedakan strain virulen dan avirulen virus ND setelah di elektroforesa DNA 100 Volt dengan konsentrasi gel agarose 3\% yang dibuktikan dengan terlihat perbedaan pola pemotongan virus ND virulen dan avirulen dari kesepuluh sampel. Pola pemotongan Enzim restriksi Hin1l ditunjukkan pada Gambar 3.

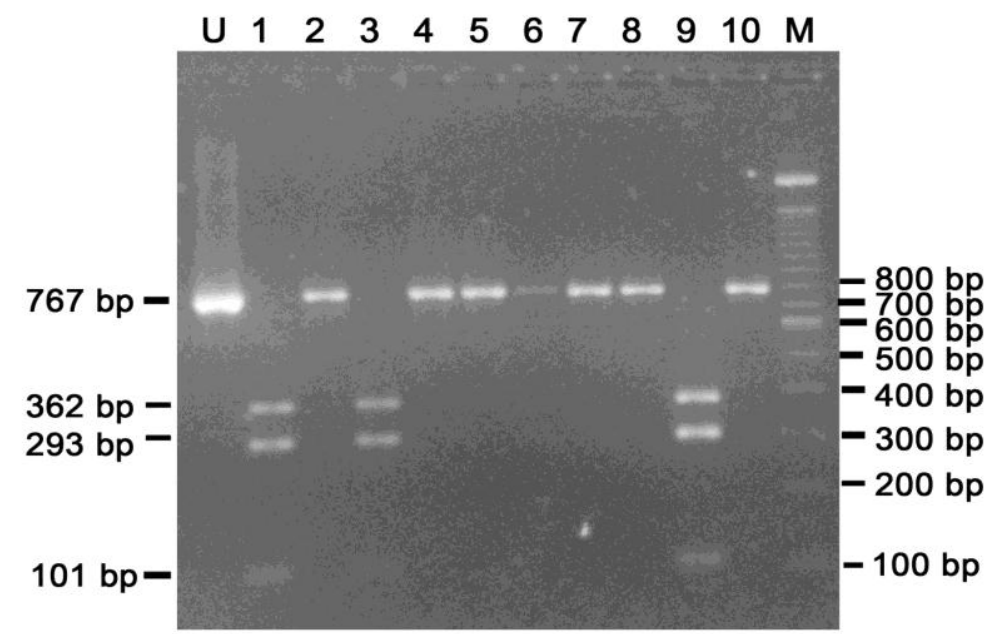

\section{Gambar 3. Hasil Amplifikasi Penentuan Patotipe Virus ND dengan Metode RT-PCR Menggunakan Enzim Restriksi Hinll}

Keterangan : Lajur U merupakan kontrol positif ND gen F yang sudah divalidasi oleh BBVet Wates dan tidak dipotong dengan enzim restriksi. Lajur 1, 3, dan 9 sampel ND terpotong menjadi beberapa fragmen DNA. Lajur 2, 4, 5, 6, 7, 8, 10 DNA sampel tidak terpotong oleh enzim restriksi. Lajur M adalah DNA Ladder 100 bp.

Virus ND yang virulen tidak memiliki restriction site Hinll, sehingga virus ND yang virulen DNA nya tidak dapat dipotong oleh enzim ini setelah diinkubasi selama 1-16 jam. Virus ND yang avirulen memiliki 3 restriction site Hin1l yaitu pada nukleotida nomor ke 293, ke 655, dan ke 666 sehingga menghasilkan 4 pola pemotongan DNA setelah di elektroforesa pada gel agarose yaitu 362 bp, 293 bp, 101 bp, dan 11 bp (Purwaningrum, 2018).

Enzim restriksi lain digunakan dalam metode analisis patotipe ND menggunakan enzim restriksi ini untuk membedakan virus ND virulen dan avirulen. Hasil pengujian analisis menggunakan enzim restriksi Apa 1 menunjukkan semua sampel tidak terpotong karena termasuk ND genotipe VII. Enzim restriksi Apa 1 berasal dari bakteri Acetobacter pasteurianus yang dapat memotong DNA virus ND genotipe II yang virulen, sedangkan 
untuk virus ND genotipe II yang avirulen seperti jenis vaksin ND Lasota DNA nya akan tetap utuh, tidak dapat terpotong oleh enzim tersebut (Mase et al., 2002; Kim et al., 2007). Enzim restriksi Apal akan memotong pada urutan nukleotida DNA sebagai berikut 5 ' ...G G G C $\mathrm{C}^{\downarrow} \mathrm{C} \ldots$ 3' $^{\prime}$ dan 3' ...C $\mathrm{C}_{\uparrow} \mathrm{C} \mathrm{C}$ G G G... 5' (Lee et al., 2008; OIE, 2012; Purwaningrum, 2014; Qin et all., 2008).

Spesivisitas primer yang digunakan dalam penelitian ini ditunjukkan dengan hasil sekuensing sampel positif yang kemudian dianalisis dengan program Basic Local Alignment Search Tool (BLAST) dari NCBI. Hasil analisis tersebut menunjukkan bahwa primer yang digunakan dalam penelitian ini 99\% identik dengan virus ND isolat KC844235.1 untuk strain yang avirulen dan 99\% identik dengan virus ND isolat HQ697259.1 pada target gen penyandi protein F. Hasil ini menunjukkan bahwa metode RT-PCR untuk mengidentifikasi virus ND dari spesimen lapangan memiliki spesivisitas hingga 99\%.

Panjang fragmen DNA hasil amplifikasi dengan primer Mase dan Kanehira (2012) adalah 767 nukleotida. Fragmen sepanjang 767 nukleotida ini diperoleh dari hasil penjajaran berganda yang didasarkan pada fragmen DNA gen penyandi protein F virus ND (Genbank) dan pola pemotongannya dengan beberapa REA dengan program CLC sequence viewer 6.8.1. Hasil analisis mengunakan program MEGA versi 5.10 ini menunjukkan bahwa semua sampel adalah benar-benar positif gen penyandi protein $\mathrm{F}$ virus ND.

Penelitian ini bertujuan mengembangkan metode RT-PCR untuk menentukan patotipe virus ND pada ayam. Satu pasang primer dipilih dari data sekuen protein struktural genom virus ND. Hasil penelitian ini menunjukkan bahwa virus ND dapat ditentukan patotipenya dengan cepat dan spesifik menggunakan metode RT-PCR dan analisis patotipe ND dengan enzim restriksi terutama dengan sampel yang berasal dari spesimen lapangan.

Penelitian ini dilakukan karena penentuan patotipe virus ND sulit ditentukan hanya dengan mengamati gejala klinis di lapangan. Metode untuk menentukan patotipe virus ND sangatlah penting dalam laboratorium diagnosa. Masalah utama dalam mendiagnosis adalah kurang cepatnya pengujian di laboratorium terhadap adanya virus ND. Diagnosis di lapangan berdasarkan atas anamnesa dari ayam yang terinfeksi dalam satu flok, perubahan pada pemeriksaan histopatologi, dan gejala klinik yang khas pada ayam yang terinfeksi. Diagnosis di lapangan harus ditegaskan dengan pemeriksaan di laboratorium melalui isolasi dan identifikasi virus. Inokulasi embrio ayam, serologi, imunofluorescen, dan pemeriksaan histopatologi adalah metode-metode yang sering digunakan untuk diagnosis infeksi virus ND. 


\section{DISKUSI}

Diagnosis yang tepat dalam usaha penanggulangan penyakit ND harus dilakukan secara dini untuk dapat melakukan tindakan pencegahan bagi unggas yang belum terinfeksi. Dapat disimpulkan bahwa kecepatan, sensitivitas, dan spesivisitas metode untuk diagnosa laboratorium terhadap penyakit ND sangatlah dibutuhkan. Pada penelitian ini, penulis melakukan optimasi metode RT-PCR untuk menentukan patotipe virus ND yang mudah dilakukan. Hasil penelitian ini pada berbagai macam sampel mengindikasikan bahwa metode RT-PCR dan analisis patotipe ND dengan enzim restriksi dengan target gen penyandi protein F dapat mengidentifikasi dan menentukan patotipe virus ND dari spesimen lapangan dengan cepat, tepat, dan akurat sehingga dapat digunakan sebagai metode diagnostik rutin untuk mendeteksi virus ND dan menentukan patotipe virus ND pada unggas.

\section{KESIMPULAN}

Hasil amplifikasi sampel ND dengan metode RT-PCR pada target gen penyandi protein $\mathrm{F}$ menunjukkan hasil positif dengan munculnya fragmen DNA sebesar $767 \mathrm{bp}$. Metode RT-PCR dan analisis patotipe ND dengan enzim restriksi dengan enzim restriksi Bam Hl dan Hinll dapat digunakan untuk menentukan patotipe virus ND dari spesimen lapangan. Hasil penentuan patotipe virus ND dengan metode RT-PCR dan analisis patotipe ND dengan enzim restriksi memiliki kecocokan dengan hasil sekuensing dalam menentukan patotipe virus ND.

\section{DAFTAR PUSTAKA}

Adi, A. A. A. M., Astawa, N. M., Putra, K. S. A., Matsumoto, Y. (2008). Deteksi Virus Penyakit Tetelo Isolat Lapangan dengan Metode Nested Reverse Transcriptase Polymerase Chain Reaction. Jurnal Veteriner. 9, 3:1-7.

Aldous, E. W., Mynn, J. K., Irvine, R.M., Alexander, D.J., Brown, I.H. (2010). A Molecular Epidemiological Investigation of Avian Paramyxovirus Type 1 Viruses Isolated from Game Birds of the Order Galliformes. Avian Pathology 39, 6, 519-524.

Dortmans, J. C. F. M., Koch, G., Rottier, P. J. M., Peeters, B. P. H. (2009). Two Genetically Closely Related Pigeon Paramyxovirus Type 1 (PPMV-1) Variants with Identical Velogenic Fusion Protein Cleavage Sites but with Strongly Contrasting Virulence. J Gen Virol. 90, 2746-2750.

Dortmans, J. C. F. M., Rottier, P. J. M., Koch, G., Peeters, B. P. H. (2011). Passaging of a Newcastle Disease Virus Pigeon Variant in Chickens Results in Selection of Viruses with 
Mutations in the Polymerase Complex Enhancing Virus Replication and Virulence dalam Virulence Determinants of Newcastle Disease Virus, hal : 77-96.

Fatchiyah, Estri Laras, Sri Widyarti dan Sri Rahayu., (2011). Biologi Molekuler, Prinsip Dasar Analitis. Penerbit Erlangga. 46 - 49.

Lee, E-K., Jeon, W-J., Kwon, J-H., Yang, C-B., Choi, K-S. 2008. Molecular Epidemiological Investigation of Newcastle Disease Virus from Domestic Ducks in Korea. Veterinary Microbiology 134, 241-248.

Kim, L. M., Suarez, D. L., Afonso, C. L. 2008. Detection of A Broad Range of Class I and II Newcastle Disease Viruses Using A Multiplex Real-Time Reverse Transcription Polymerase Chain Reaction Assay. J Vet Diagn Invest. 20,414-425.

Mase, M. dan Kanehira, K. 2012. Differentiation of APMV-1 by PCR and REA. The Journal of Veterinary Medical Science.1-10.

Miller, P. J., Decanini, E. L., Alfonso, C. L. 2010. Newcastle disease: Evolution of Genotypes and the Related Diagnostic Challenges. Infect. Gen. Evol. 10: 26-35.

Murphy, F. A., Gibbs, E. P. J., Horzinek, M. C., Studdert, M. J. 2008. Paramyxoviridae dalam Veterinary Virology. 3th edition. USA. 416-420.

Ngili, Y., 2010. Biokimia Dasar. Rekayasa Sains, Bandung.

Office International des Epizooties (OIE). 2012. Newcastle Disease. Manual Standards for Diagnostic Test and Vaccine, 576-589.

Purwaningrum, M., Verawati, Aris H. 2018. In Proceeding of International Symposium in Veterinary Science. Pathotyping of Newcastle Disease Local Isolate Virus in Poultry by RTPCR RFLP. pp.57-62. Universitas Gadjah Mada, Yogyakarta.

Purwaningrum, M., 2014. Patotyping of Newcastle Disease Local Isolate Virus in Poultry By Reverse Transcription Polymerase Chain Reaction and Restriction Endonuclease Analysis Method (RT-PCR and REA). Theses. Faculty of Veterinary Medicine, Universitas Gadjah Mada, Indonesia.

Qin, Z. M., Sun, L., Ma, B. C., Cui, Z., Zhu,Y., Kitamura, Y., Liu, W. 2008. F gene Recombination between Genotype II and VII Newcastle Disease Virus. Virus Research. 131, 299-303.

Sianita, N., Hasan, Z., Kusriningrum R. 2011. Respon Antibodi dan Protektivitas pada Ayam Pasca Vaksinasi Menggunakan Vaksin Nd Aktif Lv12. Veterinaria Medika. 4, 2.

Tan, SW., Ideris, A., Omara, A. R., Yusoff , K., Hair-Bejoa, M. 2009. Detection and Differentiation of Velogenic and Lentogenic Newcastle Disease Viruses using SYBR Green I Real-Time PCR with Nucleocapsid Gene-specific Primers. Journal of Virological Methods $160,149-156$. 
Jurnal Nasional Teknologi Terapan, Vol 2. No. 3 November 2018: 309-319 